\title{
THE ACTIVITY OF JUNIPERUS PROCERA STEM EXTRACTS AS PESTICIDES AGAINST THE BLOWFLY CHRYSOMYA ALBICEPS (DIPTERA: CALLIPHORIDAE)
}

\author{
Tarek M. Y. Elsheikh ${ }^{\text {* }}$; Usama M. Abu El-Ghiet ${ }^{2,3}$; Abdullah M. S. Alhuraysi \\ ${ }^{1}$ Zoology Department, Faculty of Science, Al-Azhar University, Cairo, Egypt \\ ${ }^{2}$ Biology Department, Faculty of Science, Jazan University, Jazan, Saudi Arabia \\ ${ }^{3}$ Plant Protection Department, Desert Research Center, Cairo, Egypt
}

\begin{abstract}
Article History:
Received: 23 December 2021

Revised: 4 January 2022

Accepted: 6 January 2022

Published Online:

14 January 2022

Keywords:

Chrysomya albiceps

Development

Fecundity

Juniperus procera

Larvicidal

*Correspondence:

Tarek Elsheikh

Zoology Department

Faculty of Science

Al-Azhar University,

Cairo, Egypt

E-mail:

telsheikh64@yahoo.com
\end{abstract}

\begin{abstract}
The blowfly (Chrysomya albiceps) larvae cause cutaneous myiasis in humans/animals. Therefore, the current study aimed to evaluate the pesticidal activity of Juniperus procera stem extracts on the $1^{\text {st }}$ instar larvae of $C$. albiceps to minimize their spread. The tested petroleum ether, acetone, and methanol extracts of $J$. procera stem showed toxic effects against the C. albiceps larvae, which were mostly dependent on the solvent type and the extract concentration. The larval mortality was found to increase as the concentration of plant extract increased. Petroleum ether extract of $J$. procera stem had a highly toxic effect at the highest concentration $(0.4 \mathrm{~g} / \mathrm{mL})$ against the larvae $\left(83.3 \% ; \mathrm{LC}_{50}=0.15 \mathrm{~g} / \mathrm{mL}\right)$, followed by methanol extract $\left(63.3 \% ; \mathrm{LC}_{50}=0.24 \mathrm{~g} / \mathrm{mL}\right)$ and acetone extract $\left(43.3 \% ; \mathrm{LC}_{50}=\right.$ $0.53 \mathrm{~g} / \mathrm{mL})$. Acetone extract of J. procera stem had a delayed toxic effect on the pupae resulting from the treated larvae. The toxicity of all $J$. procera stem extracts was extended to the adults that resulted from the treated larvae. Larval and pupal durations were affected significantly $(P<0.05)$ by methanol and acetone extracts of $J$. procera stem. All $J$. procera stem extracts exhibited remarkable effects on the fecundity, fertility, and sterility index of $C$. albiceps adult females resulting from larval treatment. Moreover, malformations among pupae and adults of C. albiceps were observed after treating the larvae with acetone and petroleum ether extracts of $J$. procera stem. Therefore, $J$. procera has promising efficacy to develop as botanical pesticide for controlling the $1^{\text {st }}$ instar larvae of $C$. albiceps.
\end{abstract}

\section{INTRODUCTION}

A large number of flies belonging to the family Calliphoridae, Muscidae, and Sarcophagidae are vectors to several diseases such as typhoid fever, cholera, tuberculosis, bacillary dysentery, and trachoma virus ${ }^{[1-3]}$. The main reason for the economic loss of livestock in the world is due to the spread of the fly species Chrysomya albiceps (Wiedemann) (Diptera: Calliphoridae) that causes cutaneous myiasis in tropics of the world. C. albiceps is known for producing myiasis in humans and animals, and transmitting pathogens 
mechanically ${ }^{[4,5]}$. In Saudi Arabia, cattle (especially sheep and goats) are the main source of animal protein. Several reports on a variety of communicable and noncommunicable diseases, which affect the economic production of livestock, are given by the Ministry of Environment, Water and Agriculture of Saudi Arabia, but with very little information about the vectors that cause or carry these diseases ${ }^{[6]}$. The pest "C. albiceps" is common in Southeast Asia, Arabian Peninsula, India, and Africa ${ }^{[7,8]}$. It had been reported in Jeddah ${ }^{[9]}$, as well as north, center, east, and south of Saudi Arabia $^{[10]}$. C. bezziana and C. albiceps are the two main species responsible for causing cutaneous myiasis in Saudi Arabia ${ }^{[11,12]}$. Myiasis by dipteran larvae causes a nuisance, less fertility/productivity, a decrease in milk production, blindness, muscle damage, and offspring death ${ }^{[13]}$. To minimize the economic losses for the cattle industry, alternative techniques for population eradication of the flies causing myiasis are needed.

Till now, controlling myiasis has used synthetic pesticides such as spiramycin, amitraz, coumaphos, ivermectin, fenthion, enrofloxacin, and diazinon by dipping methods and topical treatment ${ }^{[14-16]}$. Moreover, unfavorable effects of the use of synthetic pesticides have been recorded, such as insect resistant, death of natural enemies of pests, toxic to humans and animals, a remnant in milk and meat, as well as causing environmental pollution ${ }^{[17]}$. So, it is necessary to have alternative insecticides that have some characteristics such as accessible, simple, safe for humans and animals, and leaves no residue in animal products. Plant-derived substances may become the alternative insecticides to synthetic chemicals in control the flies and their larvae that cause myiasis.

The deserts of Saudi Arabia contain large numbers of plants of medicinal importance. There are few studies interested with these plants, most of them have been performed on plant pests and few investigations have been done on medicinal and veterinary pests such as mosquito species. Although there are some references that are interested with flies causing myiasis control among animals in some regions of the world ${ }^{[18-20]}$, very few studies $^{[21,22]}$ are available on the control of flies causing myiasis in Kingdom Saudi Arabia. So, the present study was conducted to test the toxicity of Juniperus procera stem extracts on the larvae, pupae, adult, development, and female fecundity of C. albiceps.

\section{MATERIAL AND METHODS Flies rearing}

The adult stage of $C$. albiceps was collected in 2019 from Jazan slaughterhouse and transferred to entomology lab (College of Science, Jazan University) to be reared for several generations under laboratory conditions (humidity: $60 \pm 10 \%$, temperature: $27 \pm 2^{\circ} \mathrm{C}$, and photoperiod: 12 hours dark: 12 hours light). C. albiceps was identified according to the key of Shaumar et al. ${ }^{[23]}$. Flies were reared using the previously published method ${ }^{[20]}$ with few modifications. Adults of flies were reared in wooden cages $(50 \times 50 \times 50 \mathrm{~cm})$ with wire sides and fed on sucrose solution and milk powder. A plastic plate $(15 \times 15 \mathrm{~cm})$ containing fresh beef liver has been placed inside the cage for adult laying their eggs and as a food for the larvae. The $3^{\text {rd }}$ instar larvae were selected and transferred into plastic ponds $(20 \times 30 \times 25 \mathrm{~cm})$ containing $400 \mathrm{~cm}$ of fine sawdust and left to pupate and the emergence of the adult.

\section{Extraction of plant materials}

$J$. procera (Cupressaceae) was collected from Hashr mountains $\left(17^{\circ} 27^{\prime} 02^{\prime \prime} \mathrm{N}\right.$, 4302'26"E), Jazan Governorate (Saudi Arabia). The stems of the plant were dried in the shadow at lab temperature (maximum $31^{\circ} \mathrm{C}$ ) and pulverized to powder in a hammer mill. One hundred grams of $J$. procera stem powder were extracted four times with $300 \mathrm{~mL}$ of solvents $(70 \%$ methanol or acetone, or petroleum ether) at lab temperature. After 24 hours, the supernatant was filtrated and dried in a rotary evaporator 
at $45^{\circ} \mathrm{C}$. The dry extract was weighed and then kept in the refrigerator at $4^{\circ} \mathrm{C}$ until the experiments were performed ${ }^{[21]}$.

\section{Experimental bioassay \\ Larval bioassay}

According to the method of Singh and Kaur $^{[24]}$, larval bioassay was performed with some modifications. One day old after hatching from the same egg batch, the $1^{\text {st }}$ instar larvae of $C$. albiceps were used in this bioassay. The larvae were grouped into three groups (20 larvae/group) and reared in separate rearing boxes. Plant extract concentrations were prepared by the twofold sequential dilution method using distilled water and one drop of Tween 80 to facilitate dissolving of the tested plant extracts in water. Each concentration of the plant extract $(0.4,0.2,0.1,0.05,0.25 \mathrm{~g} / \mathrm{mL})$ was put into a bowl and covered with the lid till it was used for the dipping technique. Each group of larvae was enveloped in a voile tissue and softly immersed inside the plant extract solution, while the control group was immersed in distilled water and of one drop Tween 80 . The larvae were dipped for 30 seconds and then transferred to the breeding box containing food. The larval mortality was estimated every 24 hours by touching each larva with a paintbrush and those who do not respond are considered dead. Dead larvae and pupae were isolated daily till adult emergence. Malformed larvae, pupae, and adults were isolated daily and placed in tubes containing $70 \%$ alcohol and then photographed under the microscope (GX Microscope, GXMXTL3T10, GT Vision Ltd, Suffolk, UK).

\section{Criteria studied}

Larval or pupal mortality (\%) was estimated as previously described ${ }^{[25]}$ and the mean value was taken.

- Larval mortality $(\%)=$ number of dead larvae / number of tested larvae $\times 100$

- Pupal mortality $(\%)=$ number of dead pupae / total number of resulting pupae $\times 100$ larval and pupal durations (for each one).
- Adult emergence $(\%)=\mathrm{a} / \mathrm{b} \times 100$, where: $\mathrm{a}=$ number of emerged adults, $\mathrm{b}=$ total number of resulted pupae.

Deformations in larvae, pupae, and adults were estimated by any change in shape, color, size, or failure to progress to the next stage. The growth index was estimated by using the following equation:

- Growth index = A / B, where: $\mathrm{A}=$ adult emergence $(\%), \mathrm{B}=$ mean development (days).

\section{Reproductive potential of resulting females}

The reproductive efficiency of females resulting from the treated larval was carried out according to Alhuraysi et al. ${ }^{[21]}$. The females that successfully emerge from treated larvae were picked up and transferred with normal adult males (untreated) to the wooden cages $(25 \times 25 \times 25 \mathrm{~cm})$. The males and females were fed on powdered milk and sucrose solution for three days, and then the females were transferred separately to the jar $(10 \times 10 \times 15 \mathrm{~cm})$ with part of beef liver to lay egg mass. The number of egg/raft (fecundity) after hatching was counted by using a microscope and then the mean value was taken.

The egg-hatchability (fertility) was calculated by the following equation:

- Egg-hatchability $(\%)=\mathrm{a} / \mathrm{b} \times 100$, where: $a=$ total number of hatched eggs, $b=$ total number of eggs laid.

The sterility index (SI) was calculated according to the formula of Toppozada et al. ${ }^{[26]}$ :

- Sterility $(\%)=100-[\mathrm{a} \times \mathrm{b} / \mathrm{A} \times \mathrm{B} \times 100]$, where: $\mathrm{a}=$ number of eggs laid / female in the treatment, $b=$ percentage of hatched eggs in the treatment, $\mathrm{A}=$ number of eggs laid / female in the control, $\mathrm{B}=$ percentage of hatched eggs in the control.

\section{Statistical analysis}

The lethal median concentration $\left(\mathrm{LC}_{50}\right)$ of larvae was determined based on the mortality data and probit analysis (Excel Program). The larval and pupal durations, as well as female fecundity data were subjected 
to statistical analysis by one-way ANOVA followed by Tukey's honest significance test $(P<0.05)$ to determine the difference between the control group and the different treated groups using the statistical package for social sciences (SPSS) software version 19.0 (IBM, Armonk, NY, USA).

\section{RESULTS \\ Yield of tested plant extracts in different solvents}

The obtained dry weight of $J$. procera stem extract was varied from one solvent to another, and methanol extract of $J$. procera stem produced a higher weight $(16.1 \mathrm{~g} / 100 \mathrm{~g}$ of $J$. procera stem) than acetone $(4.6 \mathrm{~g} / 100 \mathrm{~g}$ of $J$. procera stem) and petroleum ether $(3.1 \mathrm{~g} / 100 \mathrm{~g}$ of $J$. procera stem) extracts.

Toxic effects of methanolic, acetone, and petroleum ether extracts of $J$. procera stems

Table (1) indicated the toxicity of methanol, acetone, and petroleum ether extracts of $J$. procera (stem) on the larvae, pupae, and adults of $C$. albiceps. The mortality percent of larvae was found to increase mostly as the concentration of the plant extract increased; petroleum ether extract had a highly toxic effect $(83.3 \%)$ against the larvae at the highest concentration $(0.4 \mathrm{~g} / \mathrm{mL})$, followed by methanol extract $(63.3 \%)$ and acetone extract $(43.3 \%)$. It was also found that all plant extracts had no toxic effects on pupae, except for the two highest concentrations $(0.4$ and $0.2 \mathrm{~g} / \mathrm{mL})$ of acetone extract (29.4-38.8\%) and the methanol extract at $0.1 \mathrm{~g} / \mathrm{mL}(5.5 \%)$ compared with the control group $(0.0 \%)$. Moreover, the methanol extract of plant stem at $0.1 \mathrm{~g} / \mathrm{mL}$ and the two highest concentrations of acetone extract reduced the adult emergence percent to $94.5 \%, 70.6 \%$, and $61.2 \%$, respectively, compared with the control group $(100 \%)$. The methanol, acetone, and petroleum ether extracts of plant stem had a long-lasting lethal effect on the adult at all used concentrations. Some pupal malformations were observed at the two highest concentrations of plant acetone extract (30.0 and 21.4\%, respectively). Petroleum ether extract of plant stem also caused some percentages of malformation between adults developed from treated larvae (Figure 1); there was an increase in the percentages of malformed adults as the concentration of plant extract increased, it recorded $50.0 \%, 38.8 \%$, and $19.2 \%$ at plant extract concentrations of $0.4,0.2$, and $0.1 \mathrm{~g} / \mathrm{mL}$, respectively.

The results in Table (2) and Figure (2) indicated that the $\mathrm{LC}_{50}$ values were arranged as follows: petroleum ether < methanol $<$ acetone. In general, larvicide evaluation of the tested plant extracts in petroleum ether, methanol, and acetone against C. albiceps larvae revealed them to possess high, moderate, and low larvicidal activity, respectively, with $\mathrm{LC}_{50}$ values ranging from $0.15-0.53 \mathrm{~g} / \mathrm{mL}$.

\section{Effect plant extracts on larval and pupal development}

Results in Table (3) revealed that the methanol extract of plant stem caused a significant $(P<0.05)$ prolongation in the mean larval period at all used concentrations; where it recorded $6.70 \pm$ $0.97,7.08 \pm 0.97,7.55 \pm 1.49,7.26 \pm 0.43$, and $7.58 \pm 1.68$ days at $0.4,0.2,0.1,0.05$, and $0.025 \mathrm{~g} / \mathrm{mL}$, respectively, versus $6.05 \pm$ 0.61 days for the control group. Moreover, the mean pupal duration especially at the highest concentrations of plant methanol extract $(0.4$ and $0.2 \mathrm{~g} / \mathrm{mL})$ decreased significantly $(P<0.05)$ to $5.36 \pm 0.48$ and $4.60 \pm 0.48$ days, respectively, versus $5.78 \pm$ 0.77 days for the control group. The growth index was not affected as compared with the untreated group. On the other hand, the control larvae reached the pupal stage in $6.54 \pm 0.89$ days, while this duration was prolonged significantly $(P<0.05)$ to $6.82 \pm 0.97$ and $7.24 \pm 0.96$ days at the lowest concentrations $(0.05$ and $0.025 \mathrm{~g} / \mathrm{mL}$, respectively) of plant acetone extract. A significant increase $(P<0.05)$ in the mean duration of pupae at all concentrations of the plant acetone extract was observed (from $5.51 \pm 0.78$ days at the lowest concentration 


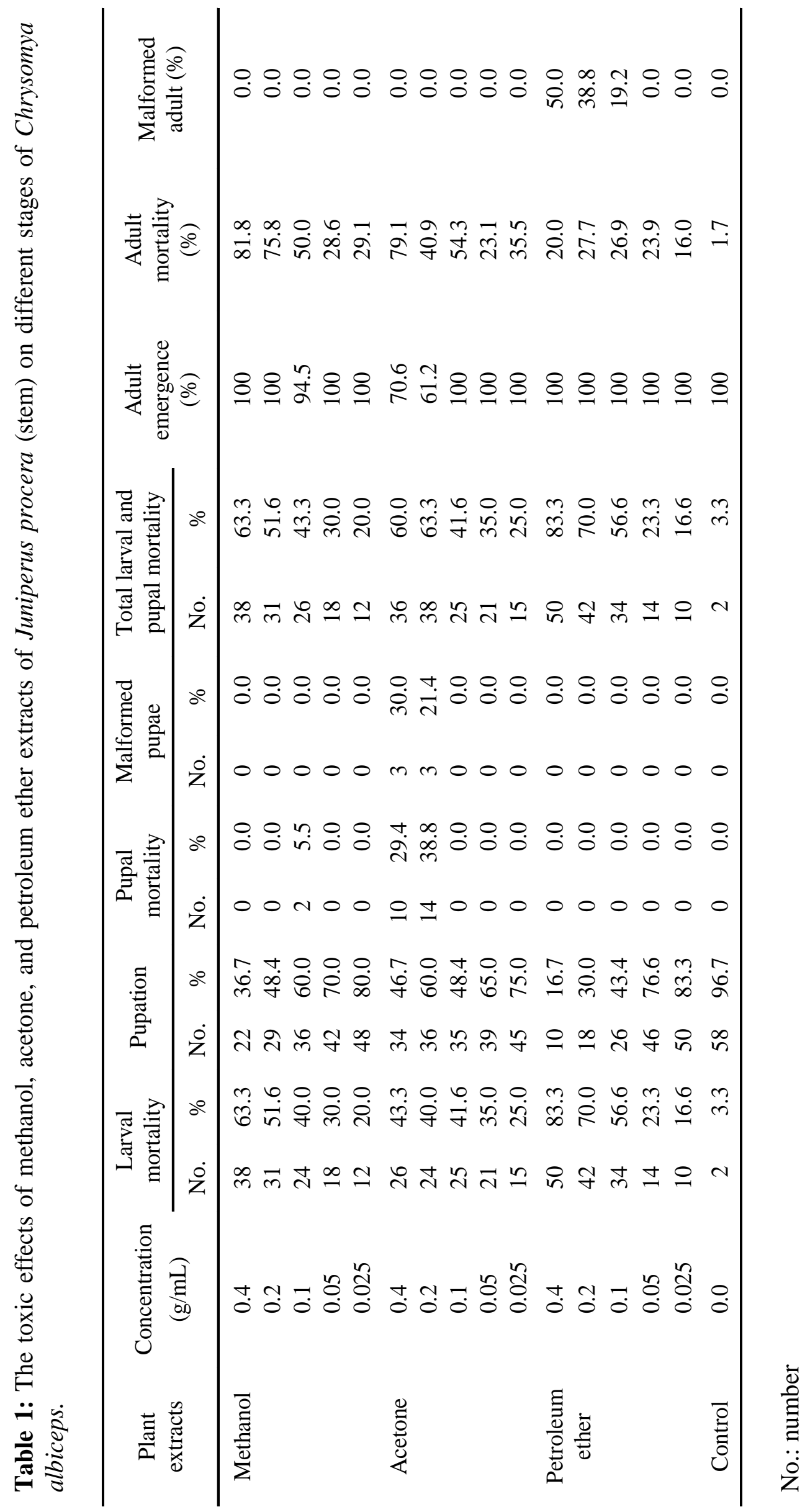




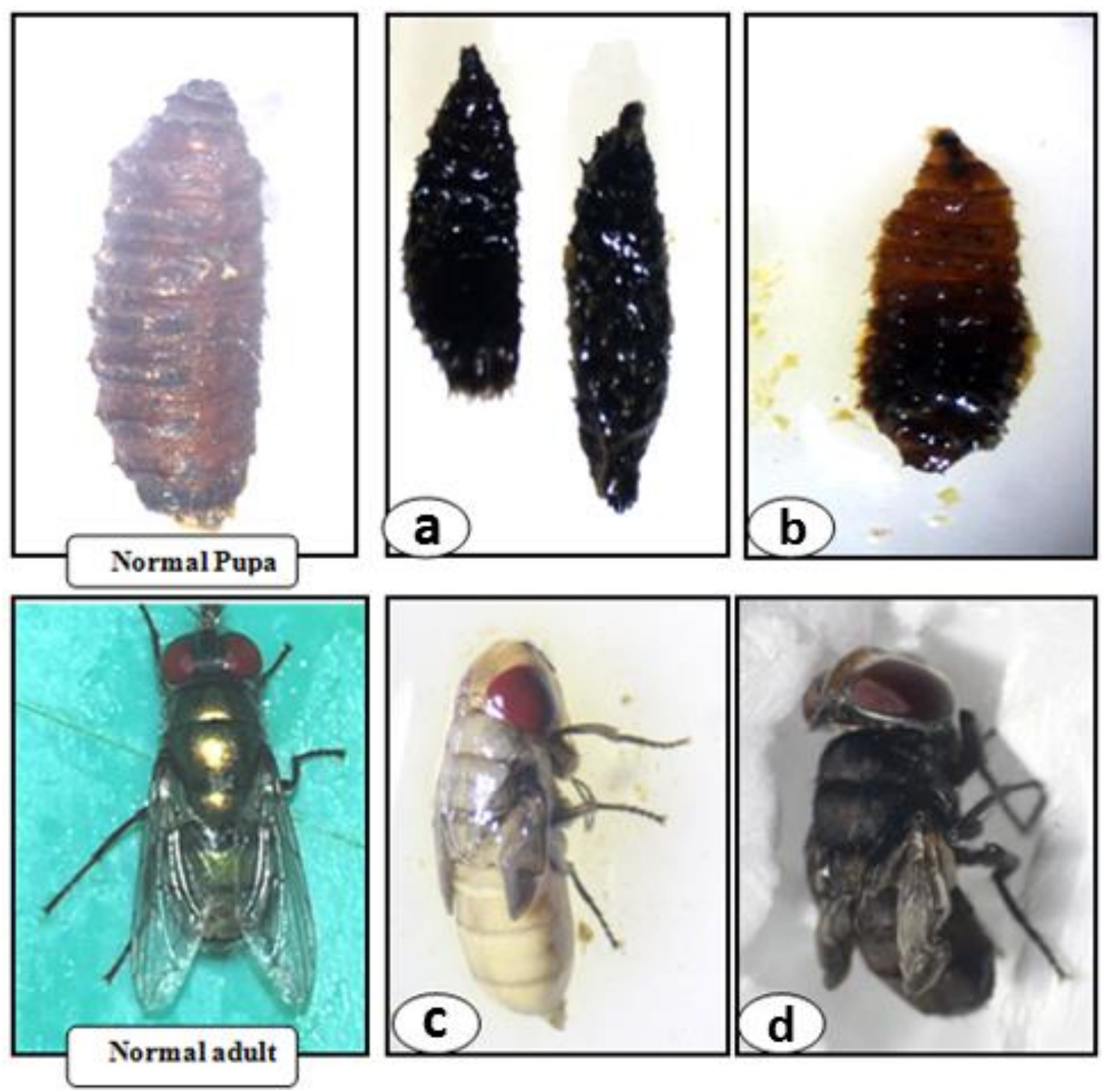

Figure 1: Morphological abnormalities occurred after treatment of $1^{\text {st }}$ larvae of Chrysomya albiceps with Juniperus procera plant extracts $(\times 160)$. (a) Dead puparium with shrunk and black colored. This feature was induced by plant acetone extract $(0.4$ and $0.2 \mathrm{~g} / \mathrm{mL})$. (b) Dead puparium with swollen posterior dark appearance resulted from larvae treated with plant acetone extract $(0.4$ and $0.2 \mathrm{~g} / \mathrm{mL})$. (c) Dead deformed adult with small wings, white (discolored) body colored, and small eyes. This feature was induced by petroleum ether extract of plant stem $(0.4, \mathrm{~g} / \mathrm{mL})$. (d) Dead deformed adult with shrink wings and dark (black) body colored resulted from the treatment of the larvae with petroleum ether extract of plant stem $(0.2$ and $0.1 \mathrm{~g} / \mathrm{mL})$.

Table 2: Relative efficiency of Juniperus procera stem extracts against Chrysomya albiceps larvae.

\begin{tabular}{lccc}
\hline Solvent & $\mathrm{LC}_{50}(\mathrm{~g} / \mathrm{mL})$ & Slope $(\mathrm{b})$ & $\begin{array}{c}\text { Correlation } \\
\text { coefficient }\left(\mathrm{R}^{2}\right)\end{array}$ \\
\hline Methanol & 0.24 & 106.2 & 0.859 \\
Acetone & 0.53 & 34.3 & 0.504 \\
Petroleum ether & 0.15 & 170.3 & 0.798 \\
\hline
\end{tabular}




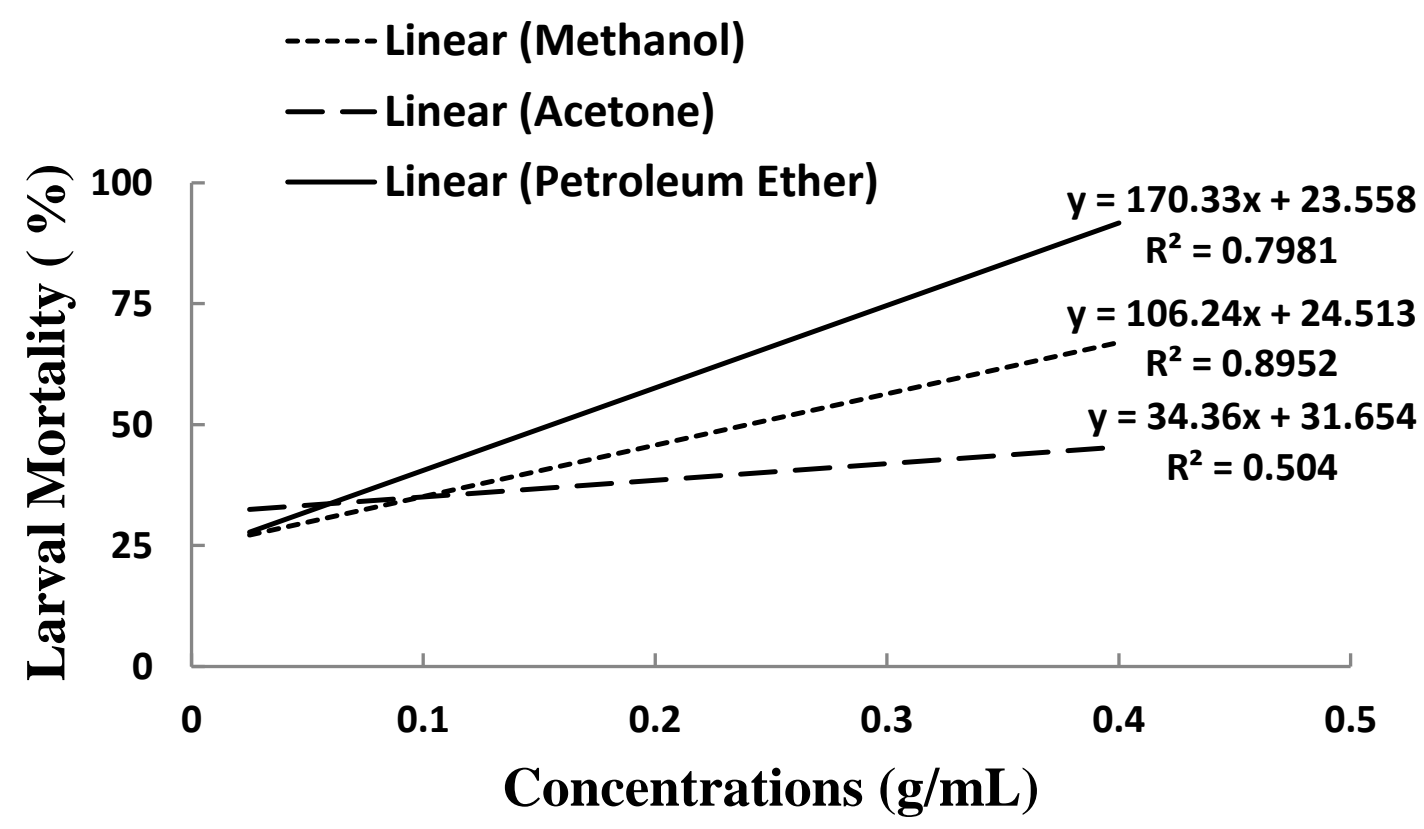

Figure 2: Insecticidal activities of methanol, acetone, and petroleum ether extracts of Juniperus procera stem against the $1^{\text {st }}$ larvae of Chrysomya albiceps.

Table 3: Larval and pupal developmental periods (days) of $1^{\text {st }}$ instar larvae of Chrysomya albiceps treated with methanol, acetone and petroleum ether extract of Juniperus procera stem.

\begin{tabular}{cccccccc}
\hline $\begin{array}{c}\text { Plant } \\
\text { extracts }\end{array}$ & $\begin{array}{c}\text { Concentration } \\
(\%)\end{array}$ & $\begin{array}{c}\text { Larval } \\
\text { duration } \\
(\text { Mean } \pm \text { SD) }\end{array}$ & Range & $\begin{array}{c}\text { Pupal } \\
\text { duration } \\
(\text { Mean } \pm \text { SD) }\end{array}$ & Range & $\begin{array}{c}\text { Total larval } \\
\text { and pupal } \\
\text { duration } \pm \text { SD }\end{array}$ & $\begin{array}{c}\text { Growth } \\
\text { Index }\end{array}$ \\
\hline Methanol & 0.4 & $6.70 \pm 0.97^{\mathrm{b}}$ & $6-8$ & $5.36 \pm 0.48^{\mathrm{b}}$ & $5-6$ & $12.06 \pm 1.45^{\mathrm{a}}$ & 8.3 \\
& 0.2 & $7.08 \pm 0.97^{\mathrm{c}}$ & $6-9$ & $4.60 \pm 0.48^{\mathrm{a}}$ & $4-5$ & $11.68 \pm 1.45^{\mathrm{a}}$ & 8.5 \\
& 0.1 & $7.55 \pm 1.49^{\mathrm{e}}$ & $6-9$ & $6.07 \pm 0.97^{\mathrm{d}}$ & $6-6$ & $13.62 \pm 2.46^{\mathrm{c}}$ & 7.0 \\
& 0.05 & $7.26 \pm 0.43^{\mathrm{d}}$ & $6-9$ & $5.66 \pm 0.86^{\mathrm{c}, \mathrm{d}}$ & $5-7$ & $12.92 \pm 1.29^{\mathrm{b}}$ & 7.7 \\
Control & 0.025 & $7.58 \pm 1.68^{\mathrm{e}}$ & $6-10$ & $5.60 \pm 0.88^{\mathrm{c}}$ & $5-7$ & $13.18 \pm 2.56^{\mathrm{b}}$ & 7.6 \\
\hline Acetone & 0.0 & $6.05 \pm 0.61^{\mathrm{a}}$ & $6-6$ & $5.78 \pm 0.77^{\mathrm{c}}$ & $5-7$ & $11.83 \pm 1.38^{\mathrm{a}}$ & 8.4 \\
& 0.4 & $6.44 \pm 0.45^{\mathrm{a}}$ & $6-7$ & $6.83 \pm 1.02^{\mathrm{e}}$ & $5-8$ & $13.27 \pm 1.47^{\mathrm{d}}$ & 5.3 \\
& 0.2 & $6.46 \pm 0.46^{\mathrm{a}}$ & $6-7$ & $6.59 \pm 0.65^{\mathrm{d}}$ & $5-7$ & $13.05 \pm 1.11^{\mathrm{c}, \mathrm{d}}$ & 4.7 \\
& 0.1 & $6.68 \pm 0.94^{\mathrm{a}, \mathrm{b}}$ & $6-8$ & $6.02 \pm 0.99^{\mathrm{c}}$ & $5-7$ & $12.70 \pm 1.93^{\mathrm{c}, \mathrm{b}}$ & 7.8 \\
Control & 0.05 & $6.82 \pm 0.97^{\mathrm{b}}$ & $6-8$ & $5.53 \pm 0.49^{\mathrm{b}}$ & $5-6$ & $12.35 \pm 1.46^{\mathrm{b}}$ & 8.1 \\
\hline Petroleum & 0.025 & $7.24 \pm 0.96^{\mathrm{c}}$ & $6-8$ & $5.51 \pm 0.78^{\mathrm{b}}$ & $5-7$ & $12.75 \pm 1.72^{\mathrm{b}}$ & 7.8 \\
ether & 0.0 & $6.54 \pm 0.89^{\mathrm{a}}$ & $6-8$ & $5.11 \pm 0.31^{\mathrm{a}}$ & $5-6$ & $11.65 \pm 1.20^{\mathrm{a}}$ & 8.6 \\
& 0.4 & $8.28 \pm 0.77^{\mathrm{a}}$ & $8-8$ & $5.10 \pm 0.30^{\mathrm{a}}$ & $5-6$ & $13.38 \pm 1.07^{\mathrm{a}}$ & 7.5 \\
& 0.2 & $8.24 \pm 0.49^{\mathrm{a}}$ & $8-8$ & $5.39 \pm 0.47^{\mathrm{b}}$ & $5-6$ & $13.63 \pm 0.96^{\mathrm{a}}$ & 7.3 \\
& 0.1 & $8.38 \pm 0.48^{\mathrm{a}}$ & $8-9$ & $5.40 \pm 0.48^{\mathrm{b}}$ & $5-6$ & $13.78 \pm 0.96^{\mathrm{a}}$ & 7.3 \\
& 0.05 & $8.40 \pm 0.47^{\mathrm{a}}$ & $8-8$ & $5.41 \pm 0.40^{\mathrm{b}}$ & $5-6$ & $13.81 \pm 0.92^{\mathrm{a}}$ & 7.2 \\
Control & 0.025 & $8.36 \pm 0.49^{\mathrm{a}}$ & $8-8$ & $5.44 \pm 0.68^{\mathrm{b}}$ & $5-7$ & $13.80 \pm 1.17^{\mathrm{a}}$ & 7.2 \\
\hline
\end{tabular}

Means followed by a different letter(s) in the same column, for each plant extract and its control, were different significantly $(P<0.05)$ from each other. SD: standard deviation. 
to $6.83 \pm 1.02$ days at the highest concentration) as compared with the control group (5.11 \pm 0.31 days). Larvae and pupae growth index was greatly affected by acetone extract at the two highest concentrations $(0.4$ and $0.2 \mathrm{~g} / \mathrm{mL})$; where it recorded 5.3 and 4.7, respectively, versus 8.6 for the control group. Petroleum ether extract of plant stem did not affect significantly $(P>0.05)$ the mean pupal duration at all used concentrations, except at the highest concentration $(0.4 \mathrm{~g} / \mathrm{mL})$; where the pupal duration was shortened significantly $(P<0.05)$ to $5.10 \pm 0.30$ days versus $5.46 \pm 0.49$ days for the untreated group. At all concentrations, the growth index was not affected by petroleum ether extract of plant stem.

\section{Effect of plant extracts on fecundity, fertility, and sterility index}

As summarized in Table (4), the plant methanol extract exerted a profound reducing action on female fecundity at all used concentrations; the fecundity was $50.0 \pm 0.0, \quad 61.0 \pm 0.0, \quad 92.5 \pm 24.0, \quad 95.3 \pm 31.8$ and $143.0 \pm 32.7 \mathrm{eggs} / \mathrm{Q}$ at $0.4,0.2,0.1,0.05$ and $0.025 \mathrm{~g} / \mathrm{mL}$, respectively, while for the control group it was $175.0 \pm 17.3 \mathrm{eggs} /$ \% . At the three highest concentrations $(0.4,0.2$, and $0.1 \mathrm{~g} / \mathrm{mL}$ ) of plant methanol extract, the hatchability rate was reduced to 18.0 , 44.2 , and $76.2 \%$, respectively, compared with $99.0 \%$ for the control group. The sterility index was increased by increasing the concentration of plant methanol extract; it recorded $94.8 \%$ and $22.4 \%$ at the highest and lowest concentration (0.4 and $0.025 \mathrm{~g} / \mathrm{mL}$, respectively). A significant decrease $(P<0.05)$ in the mean number of eggs laid at all concentrations was also observed by the plant acetone extract; it recorded $47.0 \pm 0.0$ and $151.6 \pm 41.7 \mathrm{eggs} / Q$ at the highest $(0.4 \mathrm{~g} / \mathrm{mL})$ and lowest $(0.025 \mathrm{~g} / \mathrm{mL})$ concentration, respectively, compared to $187.5 \pm 7.6 \mathrm{eggs} / 9$ for the control group. The hatchability percent decreased as the concentration of the plant acetone extract increased; the hatchability percent recorded $0.0 \%, 66.6 \%$, and $89.4 \%$ at $0.4,0.2$, and $0.1 \mathrm{~g} / \mathrm{mL}$ of plant extract, respectively, compared with $99.3 \%$ for the untreated group. The sterility index was highly affected at all concentrations of the plant acetone extract; it recorded 100 and $22.2 \%$ at the highest and lowest concentrations $(0.4$ and $0.025 \mathrm{~g} / \mathrm{mL}$, respectively). As for the plant petroleum ether extract, it had a significant deficiency effect on the average egg-laying by females resulting from the treatment of larvae. The average number was $37.0 \pm 0.0$, $72.5 \pm 35.0, \quad 120.0 \pm 38.4,147.1 \pm 36.3$, and $150.0 \pm 33.3 \mathrm{eggs} / 9$ at $0.4,0.2,0.1,0.05$, and $0.025 \mathrm{~g} / \mathrm{mL}$ of the plant petroleum

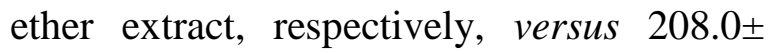
$29.6 \mathrm{eggs} / \mathrm{O}$ for the control group. The hatchability percent was $0.0,77.2,87.5$, 94.1, and $95.1 \%$ at $0.4,0.2,0.1,0.05$ and $0.025 \mathrm{~g} / \mathrm{mL}$ of the plant petroleum ether extract, respectively, versus $97.8 \%$ for the control group. The sterility index was increased by increasing the concentration of the petroleum ether extract of plant stem; it recorded 100.0, 72.5, 48.4, 32.0, and $29.9 \%$ at the concentrations: $0.4,0.2,0.1$, 0.05 , and $0.025 \mathrm{~g} / \mathrm{mL}$ of the plant extract, respectively, versus $0.0 \%$ for the control group.

\section{DISCUSSION}

The current study described in detail the impact of methanol, acetone, and petroleum ether extracts of $J$. procera stem on the development of $C$. albiceps larvae by using the dipping method. The choice of dipping techniques depends on the method used to control ectoparasites in cattle. The active constituents of the plant extracts may penetrate the body of larvae through ingestion or the cuticle. Previous researches indicated that the plant extracts can pass through the gut of larvae and destroy the epithelial cell lining and kill them ${ }^{[27]}$. Development inhibiting activity reduced pest damage effect even without killing the pest. Furthermore, in the long run, populations are reduced through disrupted metamorphosis or reduced fecundity ${ }^{[28]}$. The differences in the toxicity of chemical plant compounds on 
target species depend on the part of the plant to be extracted and the solvent used for extraction, in addition to other differences due to species responses, the developmental stages in the specific extract, the plant geographic origin, photosensitivity to compounds in the extract, and the influence on development and reproductively ${ }^{[21,29]}$. Furthermore, crude or partially purified plant extracts have been shown to be less expensive and highly effective in controlling flies than the pure compounds ${ }^{[30,31]}$.

Table 4: Effect of Juniperus procera (stem) methanol, acetone, and petroleum ether extracts on sterility index, fertility, and fecundity of female Chrysomya albiceps.

\begin{tabular}{clrrrrrr}
\hline \multirow{2}{*}{$\begin{array}{c}\text { Plant } \\
\text { Extracts }\end{array}$} & \multirow{2}{*}{$\begin{array}{c}\text { Concentration } \\
(\mathrm{g} / \mathrm{mL})\end{array}$} & \multirow{2}{*}{$\begin{array}{c}\text { No. of tested } \\
\text { females }\end{array}$} & \multicolumn{2}{c}{ Eggs laid } & \multicolumn{2}{c}{ Hatched eggs } & \multirow{2}{*}{$\begin{array}{c}\text { Sterility } \\
\text { index }(\%)\end{array}$} \\
\cline { 5 - 6 } Methanol & 0.4 & 1 & 50 & $50.0^{*}$ & 16 & 18.0 & 94.8 \\
& 0.2 & 1 & 61 & $61.0^{*}$ & 27 & 44.2 & 84.4 \\
& 0.1 & 2 & 185 & $92.5 \pm 24.0^{\mathrm{a}}$ & 141 & 76.2 & 59.3 \\
& 0.05 & 6 & 575 & $95.3 \pm 31.8^{\mathrm{a}}$ & 550 & 95.6 & 47.4 \\
& 0.025 & 9 & 1287 & $143.0 \pm 32.7^{\mathrm{b}}$ & 1212 & 94.1 & 22.4 \\
Control & 0.0 & 15 & 2625 & $175.0 \pm 17.3^{\mathrm{c}}$ & 2600 & 99.0 & 0.0 \\
\hline Acetone & 0.4 & 1 & 47 & $47.0^{*}$ & 0 & 0.0 & 100 \\
& 0.2 & 5 & 594 & $118.8 \pm 34.6^{\mathrm{a}}$ & 396 & 66.6 & 57.5 \\
& 0.1 & 4 & 445 & $111.3 \pm 32.1^{\mathrm{a}}$ & 398 & 89.4 & 46.6 \\
& 0.05 & 6 & 850 & $141.6 \pm 29.9^{\mathrm{b}}$ & 800 & 94.1 & 28.4 \\
Control & 0.025 & 9 & 1365 & $151.6 \pm 41.7^{\mathrm{a}} \mathrm{b}$ & 1305 & 95.6 & 22.2 \\
& 0.0 & 12 & 2250 & $187.5 \pm 27.6^{\mathrm{c}}$ & 2235 & 99.3 & 0.0 \\
\hline Petroleum & 0.4 & 1 & 37 & $37.0^{*}$ & 0 & 0.0 & 100 \\
ether & 0.2 & 2 & 145 & $72.5 \pm 35.0^{\mathrm{a}}$ & 112 & 77.2 & 72.5 \\
& 0.1 & 5 & 600 & $120.0 \pm 38.4^{\mathrm{b}}$ & 525 & 87.5 & 48.4 \\
& 0.05 & 8 & 1177 & $147.1 \pm 36.3^{\mathrm{c}}$ & 1108 & 94.1 & 32.0 \\
& 0.025 & 12 & 1800 & $150.0 \pm 33.3^{\mathrm{c}}$ & 1713 & 95.1 & 29.9 \\
Control & 0.0 & 15 & 3120 & $208.0 \pm 29.6^{\mathrm{d}}$ & 3053 & 97.8 & 0.0 \\
\hline
\end{tabular}

Means followed by a different letter(s) in the same column, for each plant extract and its control, were different significantly $(P<0.05)$ from each other. No.: number; SD: standard deviation. *Number of eggs laid for one female.

The results of our study recorded that all the stem extracts of $J$. procera in various solvents had toxic effects against $C$. albiceps larvae, and the toxic effect was mostly depends on the extract concentration and the type of solvent used in the extraction process. The death rate of larvae increased with increasing the concentration of the extract in most cases. Based on $\mathrm{LC}_{50}$ values, the data of our results indicated that the toxic effect of the plant petroleum ether extract was more than the plant methanol extract and the plant acetone extract. Many different plant extracts other than those used in the current study have been examined on various species of Calliphoridae flies by several authors worldwide ${ }^{[32-36]}$. In the present study, petroleum ether and methanol extract showed a good larvicidal effect against $1^{\text {st }}$ instar larvae of $C$. albiceps with $\mathrm{LC}_{50}$ 0.15 and $0.24 \mathrm{~g} / \mathrm{mL}$, respectively. The essential oil of $J$. procera had also demonstrated varying degrees of larvicidal activity against An. Arabiensis; its $\mathrm{LC}_{50}$ value was $24.65 \mathrm{mg} / \mathrm{L}^{[37]}$. The toxic effect of diethyl ether and hexane extract of Artemisia herba caused $100 \%$ larval mortality against the $3^{\text {rd }}$ instar larvae of 
C. albiceps at the concentration of 2.93 and $2.95 \mathrm{~g} / \mathrm{mL}$, respectively, by using dipping technique, while hexane and diethyl ether extract of $A$. monosperma caused $73.3 \%$ and $13.3 \%$ larval mortality at the concentrations of 7.7 and $2.5 \mathrm{~g} / \mathrm{mL}$, respectively ${ }^{[38]}$. Such results may be comparable with the results of the current study on the larvicidal activity for $J$. procera plant species against C. albiceps, whereas the petroleum ether, methanol, and acetone extracts of plant stem caused $83.3 \%, 63.3 \%$, and $43.3 \%$ larval mortality at the highest concentration $(0.4 \mathrm{~g} / \mathrm{mL})$. The existence of variations in toxicities of phytochemical compounds on target species confirms the previously mentioned suggestion of Fraternale et al. ${ }^{[29]}$. Using crude petroleum ether, chloroform, ethyl acetate, and methanol extracts of Azadirachta indica against the $3^{\text {rd }}$ instar larvae of $C$. bezziana showed that all extracts in the dipping method had toxic effects on the larval stage; the highest mortalities were recorded in methanol extract followed by chloroform, petroleum ether, and ethyl acetate extracts with $\mathrm{LC}_{50}$ values of 1.07, 1.7, 3.39, and $4.9 \mathrm{~g} / 100 \mathrm{~mL}$, respectively ${ }^{[24]}$. However, the present study showed that the highest mortalities were recorded in the petroleum ether extract of $J$. procera stem with $\mathrm{LC}_{50} 0.15 \mathrm{~g} / \mathrm{mL}$. The petroleum ether leaves extract of Artemisia absinthium at $0.4 \mathrm{~g} / \mathrm{mL}$ caused $100 \%$ larval mortality on C. albiceps with $\mathrm{LC}_{50}$ of $0.11 \mathrm{~g} / \mathrm{mL}^{[21]}$. Therefore, the test methods, differences between species, and exposure time to the test materials may be responsible for the differences among the obtained results.

In general, the plant methanol extract used in the current study induced a significant increase in the growth period of larvae at all concentrations, while the plant acetone extract induced a significant increase in the growth period of pupae at all concentrations. In addition, the plant acetone extract at all concentrations and the plant methanol extract at the lowest three concentrations induced a significant prolongation in the total developmental period (larvae and pupae), while the petroleum ether extract of pant stem had no significant effect on the total development period (larvae and pupae). Therefore, the prolongation of development was dependent mainly on the solvent used in extraction and secondarily on the extract concentration. These results are in agreement with previous reports ${ }^{[21,28,39]}$ using an aqueous extract of Pouteria sapota leaf on the post-embryonic development of Chrysomya putoria, $10 \%$ concentration of neem seed and neem seed kernel powders against $1^{\text {st }}, 2^{\text {nd }}$, and $3^{\text {rd }}$ instar larvae of the blowfly, Chysomya chloropyga, and petroleum ether, acetone, and ethanol extracts of $A$. absinthium leaves against the $1^{\text {st }}$ instar larvae of $C$. albiceps. However, Chil-Núñez et al. ${ }^{[36]}$ found the essential oil of Ocimum sanctum reduced the duration of immature stages and had a direct effect on the viability of $C$. putoria fly $\left(\mathrm{LC}_{50}=7.47\right.$ $\mathrm{mg} / \mathrm{mL}$ ). The most significant hormonal changes occur in the pupal period in the holometabolous insects. The substances extracted from plants and tested for insects control could modify specific physiological processes, such as the neurohormonal and the endocrine control of insect growth ${ }^{[40]}$.

In the present study, J. procera acetone extract had delayed toxic effects extended to the pupae. This extract also caused a decrease in the percentage of adult insects that emerged from the pupae resulting from the treated larvae. The emergence of the adult phase was dependent on the concentration and type of extract. These results are similar to the earlier results of Mohamed et al. ${ }^{[19]}$, using Commiphora molmol and Balanites aegyptiaca against the blowfly "Lucilia sericata". The seed powder of neem at a concentration of $10 \%$ also inhibits the adult emergence ${ }^{[28]}$. In addition, the percentage of adult emergence of L. sericata was markedly decreased after treatments with acetone extracts from the tree of heaven (Ailanthus altissima), dill (Anethum graveolens) and coriander

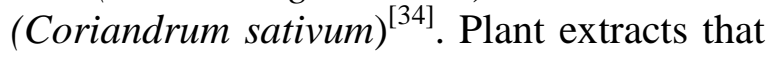
accelerate or prolong the larval duration likely caused a hormonal imbalance in the 
$\operatorname{organism}^{[41]}$, which probably affected the normal development of the structure that facilitated ecdysis in adults. In the current study, the results indicated that the toxic effects of the tested plant extracts were extended to the adult stage causing mortality ranging from $16.0 \%$ to $81.8 \%$. The plant extracts that induced more than $50 \%$ mortality in the produced adults at the highest concentration $(0.4 \mathrm{~g} / \mathrm{mL})$ were methanol and acetone extracts. At the time of this study, there are no previous studies were performed on the impact of plants extracts on survivorship of the resulted adults from treatment and growth index for Calliphoridae species, except the study of Ajayi and Muse ${ }^{[28]}$ that tested neem seed and neem seed kernel powders against the survival and the longevity of blowfly "Chrysomya chloropyga". In addition, Alhuraysi et al. ${ }^{[21]}$ concluded that the toxic effect of acetone and methanol extracts of A. absinthium against $C$. albiceps larvae was extended to pupae, and all plant extracts had delayed toxic effect on the adults.

Almost all plant extracts and their concentrations reduced significantly the fecundity and increased the sterility index of females developed from treated larvae as compared with the untreated control. The fecundity and sterility index were also dependent on the used solvent in plant extraction and the extract concentration. Furthermore, a noticeable decrease was observed in the percentage of eggs hatched by females resulting from treating larvae with petroleum ether extract of plant stem. In the present study, acetone and petroleum ether extract caused some distortions in an immature and mature stages. The developmental abnormalities induced by the plant extracts may be due to an interference with the neuroendocrine control of ecdysis ${ }^{[42]}$. Three endocrine glands in the immature stage (the corpus cardiacum, the corpus allatum, and the prothoracic gland) are known to be responsible for releasing neurohormones essential for differentiation growth and development. It has been shown that plant compounds cause a gradual degradation of all larval endocrine glands ${ }^{[43]}$. Deterioration in morphological structures indicates a general defect of the neuroendocrine system leading to prolongation of larval and pupal life. Some abnormalities in larvae and pupae after treating $L$. sericata with commercial oils from $B$. compestris, A. graveolens, T. foenum, and $R$. sativus were observed ${ }^{[32]}$; the larval deformities include crooked, small, shrunken, and darkcolored larvae, while the pupal deformities include larviform, small, and fissured larvae, and the deformities of adult include young adults and deformed legs, wings, and abdomen. The $C$. molmol oil and $B$. aegyptiaca alcoholic extract induced morphological abnormalities in L. sericata like shrunken and small larvae ${ }^{[19]}$. Varying degrees of morphogenetic abnormalities were recorded in immature stages of C. bezziana (shrunk larva and dark colored, larval-pupal intermediate) when larvae were treated with methanol, petroleum ether, chloroform, and ethyl acetate extracts of A. indica $^{[24]}$. The essential oil extracted from Ocimum sanctum with 5\% and $10 \%$ concentrations exhibited morphological alterations of $C$. putoria adults ${ }^{[36]}$. The larval and pupal deformation was also recorded when testing methanol and acetone extract of $A$. absinthium on C. albiceps larvae ${ }^{[21]}$.

In conclusion, the plant extracts used in the present study not only killed larvae when used at high concentrations, but also inhibited metamorphosis and caused morphological deformities at sub-lethal concentrations. These extracts can inhibit the emergence of the adult. Further studies will be conducted to test the efficacy of these plant extracts on field strains, which may lead to the future development of effective natural control against blowflies and may be incorporated with other pest control programs.

\section{FUNDING SOURCE DISCLOSURE}

This research received no specific grant from any funding agency in the public, commercial, or not-for-profit sectors. 


\section{CONFLICT OF INTEREST}

The authors have no potential financial conflict of interest.

\section{AUTHORS' CONTRIBUTIONS}

AMSA: Master's student responsible for the project, participated in the planning and execution of bioassays, data analysis, and writing of the manuscript. TMYS: Project supervisor; guided the data collection and reviewed the manuscript. UMAE: Assistant project supervisor, assisted in the setup and evaluation of experiments in the laboratory and in the analysis of the data. All authors have read and approved the manuscript.

\section{REFERENCES}

[1] Greenberg, B. (1973). Flies and Diseases. Biology and Disease Transmission, Volume 2. Princeton University Press, Princeton, NJ, USA.

[2] Zumpt, F. (1965). Myiasis in Man and Animals in the Old World: A Textbook for Physicians, Veterinarians, and Zoologists. Butterworths, London, UK.

[3] Patton, W. S. and Cushing, E. C. (1934). Studies on the higher dipteral of medical and veterinary importance. A revision of the genera of subfamily Calliphorinae based on a comparative study of the male and female terminalia: the Genus Chrysomya Robineau-Desvoidy (sens. lat.). Ann Trop Med Parasit, 28(2): 217-223.

[4] Reigada, C. and Godoy, W. A. C. (2005). Dispersal and predation behavior in larvae of Chrysomya albiceps and Chrysomya megacephala (Diptera: Calliphoridae). J Insect Behav, 18(4): 543-555.

[5] Marinho, C. R.; Barbosa, L. S.; Azevedo, A. C. G. et al. (2006). Diversity of Calliphoridae (Diptera) in Brazil's tingua biological reserve. Braz J Biol, 66(1A): 95-100.

[6] Bosly, H. A. M. (2010). Prevalence of dipterous flies with veterinary importance in selected sheep's farms and slaughterhouses in Jazan, Saudi Arabia. Egypt Acad J Biol Sci (A. Entomology), 3(2): 63-73.

[7] Norris, K. R. and Murray, M. D. (1964). Notes On the Screw-Worm Fly, Chrysomya bezziana (Diptera: Calliphoridae), As a Pest of Cattle in New Guinea. CSIRO, Melbourne, Australia (https://doi.org/10.25919/nrz k-0y44).

[8] Spradbery, J. P. and Kirk, J. (1992). Incidence of old world screw-worm fly in the United Arab Emirates. Vet Rec, 130(2): 33 (DOI: 10.1136/vr.130. 2.33).

[9] Al-Shareef, L. A. H. and Almazyad, M. M. F. (2016 ). Comparative study of fly species diversity and their succession on rabbit carcasses in three different habitats in Jeddah city, Kingdom of Saudi Arabia. Aust J Basic \& Appl Sci, 10(18): 336-345.

[10] Setyaningrum, H. and Al Dhafer, H. M. (2014). The Calliphoridae the blowflies (Diptera: Oestroidea) of Kingdom of Saudi Arabia. Egypt Acad J Biol Sci (A. Entomology), 7(1): 49-139.

[11] Badawi, A. (1994). Arthropods of Medical and Veterinary Importance in the kingdom of Saudi Arabia. King Saud Univ Press, Riyadh, Saudi Arabia.

[12] Alahmed, A. M. (2001). Incidence of myiasis in sheep caused by Chrysomya bezzianain Saudi Arabia. J King Saud Univ, 14(2): 109-112.

[13] Sotiraki, S. and Hall, M. J. R. (2012). A review of comparative aspects of myiasis in goats and sheep in Europe. Small Rumin Res, 103: 75-83.

[14] Chemonges-Nielson, S. (2003). Chrysomya bezziana in pets dogs in Hongkong: a potential threat to Australia. Aust Vet J, 81(4): 202-205.

[15] Osorio, J.; Moncada, L.; Molano, A. et al. (2006). Role of ivermectin in the treatment of severe orbital myiasis due to Cochliomyia hominivorax. Clin Infect Dis, 43(6), e57-e59. 
[16] Wardhana, A. H. (2006). Chrysomya bezziana, the cause of myiasis on animal and human: problem and control. WARTAZOA, 16(3), 146-159.

[17] Gealh, W. C.; Ferreira, G. M.; Farah, J. G. et al. (2009). Treatment of oral myiasis caused by Cochlomya hominivorax: two cases treated with Ivermectin. Br J Oral Maxillofac Surg, 47: 23-26.

[18] Alahmed, A. M. (2004). Myiasis in sheep farms in Riyadh region, Saudi Arabia. J. Egypt Soc Parasitol, 34: 153-60.

[19] Mohamed, H. S.; Fahmy, M. M.; Attia, M. M. et al. (2016). The insecticidal activity of two medicinal plants (Commiphora molmol) and (Balanites aegyptiaca) against the blowfly Lucilia sericata (Diptera: Calliphoridae). Int J Adv Res Biol Sci, 3(3): 144-158.

[20] Singh, A. and Kaur, J. (2017). Activity of foliage extracts of Ricinus communis L. (Euphorbiaceae) against myiasis causing larvae of Chrysomya bezziana Villeneuvae (Diptera: Calliphoridae). J Vet Med Res, 4: 1070.

[21] Alhuraysi, A. M. S.; Elsheikh, T. M. Y. and Abu El-Ghiet, U. M. (2021). The insecticidal activity of Artemisia absinthium leaves extracts against Blowfly, Chrysomya albiceps (Calliphoridae). Egypt Acad J Biol Sci (F. Toxicology \& Pest Control), 13: 115-127.

[22] Al-Jameeli, M. M. (2021). Larvicidal activity of selected plant extracts against the screwworm fly Chrysomya albiceps. Biosci Biotech Res Asia, 18(3): 487-495.

[23] Shaumar, N. F.; Mohammed, S. K. and Mohammed S. A. (1989). Keys for identification of species of family Calliphoridae (Diptera) in Egypt. J Egypt Soc Parasitol, 19(2): 669-681.

[24] Singh, A. and Kaur, J. (2016). The bioefficacy of crude extracts of Azadirachta indica (Meliaceae) on the survival and development of myiasiscausing larvae of Chrysomya bezziana (Diptera: Calliphoridae). Trop Anim Health Prod, 48(1): 117-124.

[25] Briggs, J. N. (1960). Reduction of adult house-fly emergence by the effective Bacillus spp. on the development of immature forms. $\mathrm{J}$ Insect pathology, 2(4): 418-432.

[26] Toppozada, A.; Abdallah, S. and Eldefrawi, M. E. (1966). Chemosterilization of larvae and adults of the Egyptian cotton leafworm, Prodenia litura, by apholate, metepa, and tepa. $\mathrm{J}$ Econo Entomo, 59(5): 1125-1128.

[27] Sidi, M. B.; Touhidul Islam, M. D.; Ibrahim, Y. et al. (2012) Effect of insecticide residue and spray volume application of azadirachtin and rotenone on Trichogramma papilionis (Hymenoptera: Trichogrammatidae). Int J Agric Biol, 14(5): 805-810.

[28] Ajayi, A. A. and Muse, W. A. (2015). Efficacy of neem seed kernel powders on the survival, longevity and fecundity of blowfly Chrysomya chloropyg (Wied.) (Diptera: Calliphoridae). IOSR-JPBS, 10(3): 72-85.

[29] Fraternale, D.; Flamini, G. and Ricci, D. (2015). Essential oil composition and antigermination activity of Artemisia dracunculus (Tarragon). Nat Prod Commun, 10(8): 1469-1472.

[30] Jang, Y.-S.; Baek, B.-R.; Yang, Y.-C. et al. (2002). Larvicidal activity of leguminous seeds and grains against Aedes aegypti and Culex pipiens pallens. J Am Mosq Control Assoc, 18(3): 210-213.

[31] Cavalcanti, E. S. B.; de Morais, S. M.; Lima M. A. A. et al. (2004). Larvicidal activity of essential oils from Brazilian plants against Aedesa egypti L. Mem Inst Oswaldo Cruz, Rio de Janeiro, 99(5): 541-544.

[32] Khater, H. F. and Khater, D. F. (2009). The insecticidal activity of four medicinal plants against the 
blowfly Lucilia sericata (Diptera: Calliphoridae). Int J Dermatol, 48(5): 492-497.

[33] Mustika, A. A.; Hadi, U. K.; Wardhana, A. H. et al. (2016). The efficacy of larvicides of leaves of yam bean (Pachyrhizus erosus) as botanical insecticides against fly larvae myiasis Chrysomya bezziana. IOSR J Pharm, 6(3): 76-81.

[34] Khater, K. S. (2017). Efficacy of some plant extracts on Lucilia Sericata (Meigen) (Diptera: Calliphoridae). Egypt Acad J Biol Sci (F. Toxicology \& Pest Control), 9: 1-7.

[35] Suwannayod, S.; Sukontason, K. L.; Somboon, P. et al. (2018). Activity of kaffir lime (Citrus Hystrix) essential oil against blow flies and house fly. Southeast Asian J Trop Med Public Health, 49: 32-45.

[36] Chil-Núñez, I.; Mendonça, P. M.; Escalona-Arranz, J. C. et al. (2018). Insecticidal effects of Ocimum sanctum var. cubensis essential oil on the diseases vector Chrysomya putoria. J Pharm Pharmacogn Res, 6(3): 148-157.

[37] Karunamoorthi, K.; Girmay, A. and Fekadu, S. (2014). Larvicidal efficacy of Ethiopian ethnomedicinal plant Juniperus procera essential oil against afrotropical malaria vector Anopheles arabiensis (Diptera: Culicidae). Asian Pac J Trop. Biomed, 4(Suppl 1): S99S106.

[38] Abdel-Shafy, S.; El-Khateeb, R. M; Soliman, M. M. M. et al. (2009). The efficacy of some wild medicinal plant extracts on the survival and development of third instar larvae of Chrysomya albiceps (Wied) (Diptera: Calliphoridae). Trop Anim Health Prod, 41(8): 1741-1753.

[39] Carriçoa, C.; Pinto Z. T.; Dutok, C. M. S. et al. (2014). Biological activity of Pouteria sapota leaf extract on postembryonic development of blowfly Chrysomya putoria (Wiedemann, 1818) (Calliphoridae). Rev Bras Farmacogn, 24(3): 304-308.

[40] Cabral, M. M. D.; Mendonça, P. M. and Gomes, C. M. D. et al. (2007). Biological activity of yangambin on the postembryonic development of Chrysomya megacephala (Diptera: Calliphoridae). J Med Entomol, 44(2): 249-255.

[41] Muse, W. A.; Kehinde, T. O.; Olodi, A. O. et al. (2002). Effect of some pulverized plant extracts on oviposition, hatching and development of larvae of Aedea egypti (L.). Environment \& Ecology, 20(4): 810817.

[42] Schmutterer, H. (1990). Properties and potential of natural pesticides from the neem tree Azadirachta Indica. Annu Rev Entomol, 35: 271-297.

[43] Meurant, K.; Sernia, C. and Rembold, H. (1994). The effects of azadirachtin A on the morphology of the ring complex of Lucilia cuprina (Wied) larvae (Diptera: Insecta). Cell Tissue Res, 275: 247-254.

\section{How to cite this article:}

Elsheikh, T. M. Y.; Abu El-Ghiet, U. M. and Alhuraysi, A. M. S. (2022). The activity of Juniperus procera stem extracts as pesticides against the blowfly Chrysomya albiceps (Diptera: Calliphoridae). Egyptian Journal of Zoology, 77: 14-28 (DOI: 10.21608/ejz.2022.112699.1067). 


\section{نشاط مستخلصات ساق نبات العرعر "Juniperus procera" كمبيدات حشرية ضد فيابة}

ذُبابة "Chrysomya albiceps" (رنبة: Diptera ، فصيلة: Calliphoridae)

\section{طارق محمد يسرى الشيخ'، أسامة محمد أبو الغيط233 ، عبد الله محمد سلمان الحريصي²}

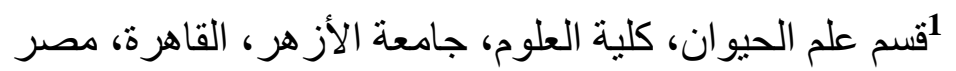

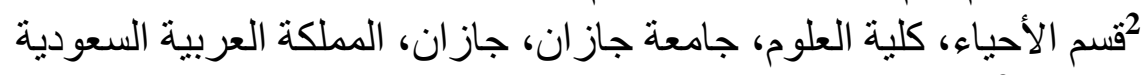

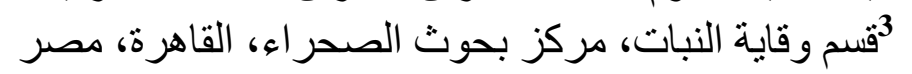

تسبب يرقات ذبابة "Chrysomya albiceps" النغف الجلدي في البشر والحيو انات. لذلك، هدفت الدراسة الحالية

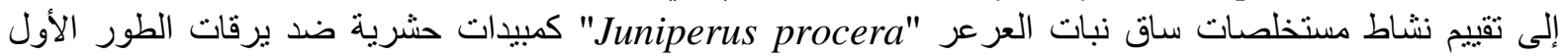

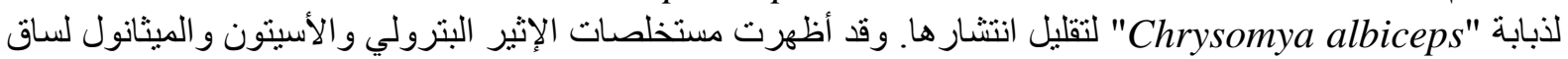

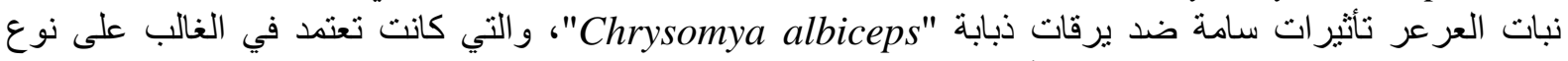

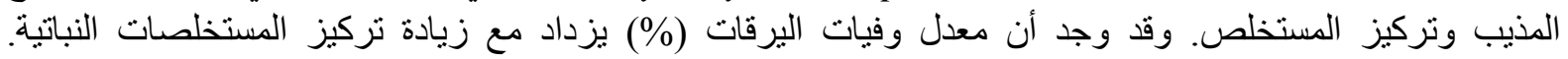

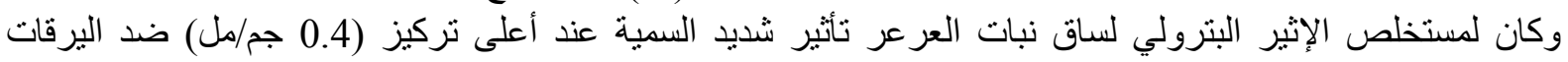

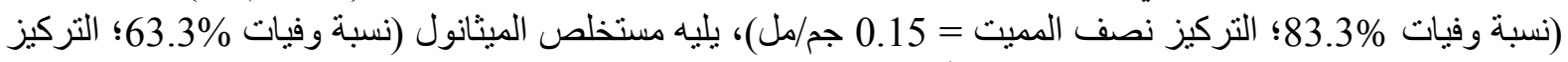

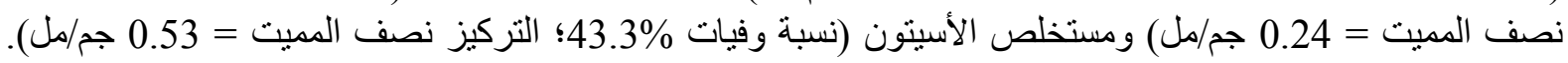

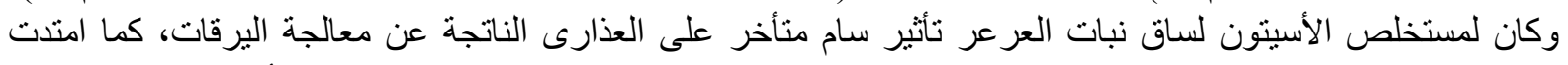

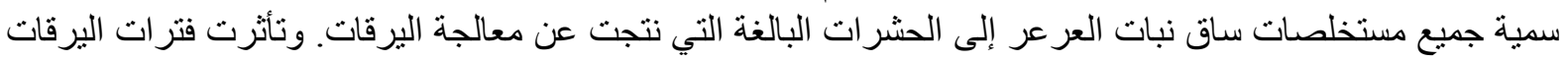

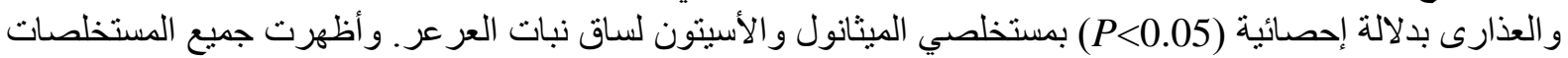

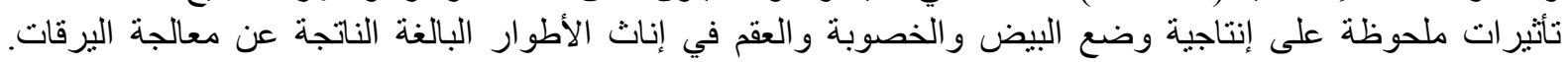

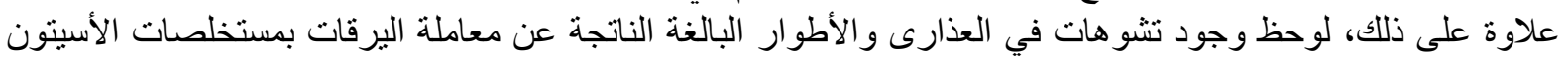

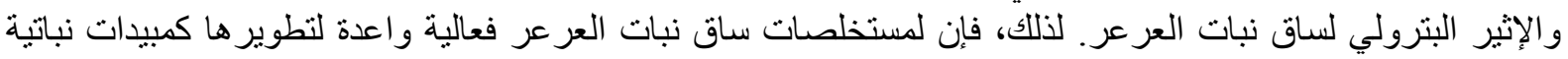

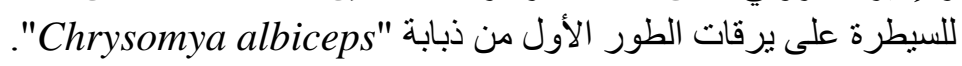

